\title{
Adolescent vaccination with BNT162b2 (Comirnaty, Pfizer-BioNTech) vaccine and effectiveness of the first dose against COVID-19: national test-negative case-control study, England
}

\author{
Annabel A Powell, ${ }^{1}$ Freja Kirsebom, ${ }^{1}$ Julia Stowe, ${ }^{1}$ Kelsey McOwat, ${ }^{1}$ Vanessa Saliba, ${ }^{1}$ Mary E \\ Ramsay, ${ }^{1,2}$ Jamie Lopez-Bernal, ${ }^{1,2,3}$ Nick Andrews, ${ }^{1,2^{*}}$ Shamez N Ladhani ${ }^{1,4^{*}}$ \\ * Joint senior authors
}

1. UK Health Security Agency, London, United Kingdom

2. NIHR Health Protection Research Unit in Vaccines and Immunisation, London School of Hygiene and Tropical Medicine, London, United Kingdom

3. NIHR Health Protection Research Unit in Respiratory Infections, Imperial College London, London, United Kingdom

4. Paediatric Infectious Diseases Research Group, St George's University of London, London, UK

\begin{abstract}
Adolescents in the UK were recommended to have their first dose of mRNA vaccine during a period of high community transmission due to the highly transmissible Delta variant, followed by a second dose at an extended interval of 8-12 weeks. We used national SARS-CoV-2 testing, vaccination and hospitalisation data to estimate vaccine effectiveness (VE) using a test-negative case-control design, against PCR-confirmed symptomatic COVID-19 in England. VE against symptomatic disease increased to $80 \%$ within two weeks of the first dose of BNT162b2 vaccine (higher than in adults aged 18-64 years) and then declines rapidly to $40 \%$ within 8 weeks (similar to adults). Early data in 16-17-yearolds also indicate high protection against hospitalisation and a rapid increase in VE against symptomatic COVID-19 after the second dose. Our data highlight the importance of the second vaccine dose for protection against symptomatic COVID-19 and raise important questions about the objectives of an adolescent immunisation programme. If prevention of infection is the primary aim, then regular COVID-19 vaccine boosters will be required.
\end{abstract}


medRxiv preprint doi: https://doi.org/10.1101/2021.12.10.21267408; this version posted December 11,2021 . The copyright holder for this preprint (which was not certified by peer review) is the author/funder, who has granted medRxiv a license to display the preprint in It is made available under a CC-BY-NC-ND 4.0 International license .

\section{Background}

Children and adolescents have a low risk of severe COVID-19. ${ }^{1}$ In the UK, COVID-19 vaccination for adults began in December 2020. ${ }^{2}$ Because of concerns about rare but potentially severe myocarditis after mRNA vaccination, mainly after the second dose in young adult males, the UK Joint Committee on Vaccination and Immunisation (JCVI) initially recommended one dose for 16-17-year-olds from 4 August $2021,^{3}$ and recommended against vaccinating $12-15$-year-olds because of marginal riskbenefits, ${ }^{4}$ although UK ministers subsequently recommended vaccinating this group with BNT162b2 (Comirnaty, Pfizer-BioNTech) or mRNA-1273 (Spikevax, Moderna) from 13 September 2021 to prevent education disruption. ${ }^{5}$ Contrary to the authorised 3-week interval, the UK recommends 8-12 weeks between doses, because of the high protection the first dose provides and higher antibody responses after a later second dose. ${ }^{6}$ The UK strategy provided a unique opportunity to assess single-dose mRNA vaccine effectiveness (VE) in adolescents during a period of high community infection with the highly-transmissible Delta variant.

\section{Methods}

We used a test-negative case-control design to estimate VE after one BNT162b2 dose against PCRconfirmed symptomatic COVID-19 in England, as described previously. ${ }^{7,8}$ Vaccination status in symptomatic 12-15-year-olds and 16-17-year-olds with PCR-confirmed SARS-COV-2 infection was compared with vaccination status in symptomatic adolescents in the same age-groups who had a negative SARS-COV-2 PCR test. Because of small numbers, we only assessed VE against hospitalisation after dose one in 16-17-year-olds (full details in Supplement 1). 
medRxiv preprint doi: https://doi.org/10.1101/2021.12.10.21267408; this version posted December 11,2021 . The copyright holder for this preprint (which was not certified by peer review) is the author/funder, who has granted medRxiv a license to display the preprint in It is made available under a CC-BY-NC-ND 4.0 International license .

\section{Results}

From week 322021 onwards, there were 404,744 eligible tests for 12-15-year-olds and 138,273 for 16-17-year-olds, with a test date within 10 days of symptom onset date, and which could be linked to the National Immunisation Management system (match rate: $93.2 \%$ and $91.0 \%$, respectively)

(Supplement 2\&3). Vaccine uptake and confirmed infections by age-group and over time are summarised in Supplement 4.

For 16-17-year-olds, VE against symptomatic disease after dose one peaked at 2 weeks (75.9\%; 95\% Cl 74.3-77.4), declined gradually and plateaued just under 40\% after 8-9 weeks (Figure 1, Supplement 5). After dose two, VE increased and reached $94.6 \%(95 \% \mathrm{Cl} 92.8-95.9)$ at $2-9$ weeks (Supplement 5) VE against hospitalisation at $14+$ days post-dose one was $84.5 \%(95 \% \mathrm{Cl}, 64.6$ 93.2).(Supplement 6)

Since 12-15-year-olds were vaccinated after 16-17-year-olds, follow-up was limited to 8-9 weeks post-dose one but followed a similar trajectory, with VE peaking at two weeks $(75.4 \%$; $95 \% \mathrm{Cl}, 73.9$ 76.9) before declining to $46.8 \%(95 \% \mathrm{Cl}, 14.9-66.7)$ by $8-9$ weeks. (Figure 1, Supplement 5).

Similar to adolescents, VE in adults also peaked at two weeks after dose one, but reached a lower peak of $63.0 \%(95 \% \mathrm{Cl}, 62.2-63.8)$ in $18-39$ year-olds and $54.5 \%(95 \% \mathrm{Cl}, 49.7-58.8)$ in $40-64$ year-olds, with more gradual decline to $41.4 \%$ and $36.0 \%$ after $10-12$ weeks (Figure 1, Supplement 5). After dose two, VE peaked after one week at $92.2 \%(95 \% \mathrm{Cl}, 91.9-92.5)$ for $18-39$ year olds and $87.1 \%$ $(95 \% \mathrm{Cl}, 85.5-88.5)$ before declining to $88.7 \%(95 \% \mathrm{Cl}, 88.5-88.8)$ and $84.1 \%(95 \% \mathrm{Cl}, 83.6-84.5)$, respectively, at 2-9 weeks (Figure 1, Supplement 5).

\section{Discussion}

VE in both 12-15-year-olds and 16-17-year-olds peaked higher than in adult populations but, declined rapidly to around $40 \%$ by $8-12$ weeks after the first dose. In 16-17-year-olds, VE after dose 2 
medRxiv preprint doi: https://doi.org/10.1101/2021.12.10.21267408; this version posted December 11,2021 . The copyright holder for this preprint (which was not certified by peer review) is the author/funder, who has granted medRxiv a license to display the preprint in It is made available under a CC-BY-NC-ND 4.0 International license .

increased rapidly and plateaued at $95 \%$ at 2-9 weeks, also higher than adult VE in this period. This is, so far, the only VE evaluation after a single mRNA dose in adolescents. Pre-licensure trials reported 93\% (mRNA-1273) to 100\% (BNT162b2) efficacy in preventing COVID-19 among 12-15 year-olds from 7 days (BNT162b2) or 14 days (mRNA-1273) after two doses given 3-4 weeks apart, ${ }^{9,10}$ but the short interval between doses prevents comparison with our cohort. Real-world VE data against two BNT162b2 doses includes a US study using a similar test-negative case-control design estimating 93\% (95\%Cl, 83\%-97\%) VE against hospitalisation during June-September $2021,{ }^{11}$ and another reporting $81 \%$ VE (95\% Cl, -55 to 90\%) VE against hospitalisation in 12-15-year-olds, although this included only 45 cases, ${ }^{12}$ whilst early Israeli data estimated $91.5 \%(95 \% \mathrm{Cl}, 88.2 \%-93.9 \%)$ VE against SARSCoV-2 infection in $12-15$-year-olds. ${ }^{13}$

VE against symptomatic COVID-19 wanes quickly after the first dose and is also expected to wane after the second dose. The adolescent immunisation programme as a stand-alone intervention is unlikely to sustain suppression of infections in the medium-to-long term. If the aim of the programme is to reduce infections, then regular boosters will likely be needed.

\section{Funding: None}

Conflict of interest: None

Ethics approval: UKHSA has legal permission, provided by Regulation 3 of The Health Service (Control of Patient Information) Regulations 2002, to process patient confidential information for national surveillance of communicable diseases and as such, individual patient consent is not required to access records. 
medRxiv preprint doi: https://doi.org/10.1101/2021.12.10.21267408; this version posted December 11, 2021. The copyright holder for this preprint (which was not certified by peer review) is the author/funder, who has granted medRxiv a license to display the preprint in It is made available under a CC-BY-NC-ND 4.0 International license .

\section{REFERENCES}

1. Ladhani SN, Amin-Chowdhury Z, Davies HG, et al. COVID-19 in children: analysis of the first pandemic peak in England. Arch Dis Child 2020; 105(12): 1180-5.

2. JCVI. Optimising the COVID-19 vaccination programme for maximum short-term impact. 2021. https://www.gov.uk/government/publications/prioritising-the-first-covid-19-vaccine-dosejcvi-statement/optimising-the-covid-19-vaccination-programme-for-maximum-short-term-impact (accessed 23rd November 2021).

3. Public Health England. JCVI issues updated advice on COVID-19 vaccination of young people aged 16 to 17. 2021.

4. Public Health England. JCVI issues updated advice on COVID-19 vaccination of children aged 12 to 15.2021.

5. Public Health England. Universal vaccination of children and young people aged 12 to 15 years against COVID-19. 2021.

6. Amirthalingam G, Bernal JL, Andrews NJ, et al. Higher serological responses and increased vaccine effectiveness demonstrate the value of extended vaccine schedules in combatting COVID-19 in England. medRxiv 2021: 2021.07.26.21261140.

7. Andrews N, Stowe J, Kirsebom F, Gower C, Ramsay M, Bernal JL. Effectiveness of BNT162b2 (Comirnaty, Pfizer-BioNTech) COVID-19 booster vaccine against covid-19 related symptoms in England: test negative case-control study. medRxiv 2021: 2021.11.15.21266341.

8. Lopez Bernal J, Andrews N, Gower C, et al. Effectiveness of the Pfizer-BioNTech and OxfordAstraZeneca vaccines on covid-19 related symptoms, hospital admissions, and mortality in older adults in England: test negative case-control study. BMJ 2021; 373: n1088.

9. Frenck RW, Jr., Klein NP, Kitchin N, et al. Safety, Immunogenicity, and Efficacy of the BNT162b2 Covid-19 Vaccine in Adolescents. N Engl J Med 2021; 385(3): 239-50.

10. Ali K, Berman $\mathrm{G}$, Zhou H, et al. Evaluation of mRNA-1273 SARS-CoV-2 Vaccine in Adolescents. N Engl J Med 2021.

11. Olson SM NM, Halasa NB, et al. Effectiveness of Pfizer-BioNTech mRNA Vaccination Against COVID-19 Hospitalization Among Persons Aged 12-18 Years - United States, June-September 2021. MMWR Morb Mortal Wkly Rep 2021 2021; (70): 1483-8.

12. Tartof SY, Slezak JM, Fischer H, et al. Effectiveness of mRNA BNT162b2 COVID-19 vaccine up to 6 months in a large integrated health system in the USA: a retrospective cohort study. Lancet 2021; 398(10309): 1407-16.

13. Glatman-Freedman A, Hershkovitz Y, Kaufman Z, Dichtiar R, Keinan-Boker L, Bromberg M. Effectiveness of BNT162b2 Vaccine in Adolescents during Outbreak of SARS-CoV-2 Delta Variant Infection, Israel, 2021. Emerg Infect Dis 2021; 27(11): 2919-22. 
Figure 1. Vaccine effectiveness with 95\% confidence intervals against symptomatic, PCR-confirmed COVID-19 among adolescents and adults after one and two doses of BNT162b2 (Comirnaty, Pfizer-BioNTech in England. Children aged 12-15 years have yet to receive their second dose of vaccine in England.

\section{VACCINE EFFECTIVENESS AFTER DOSE 1:}

\section{a) 12-15-year-olds}

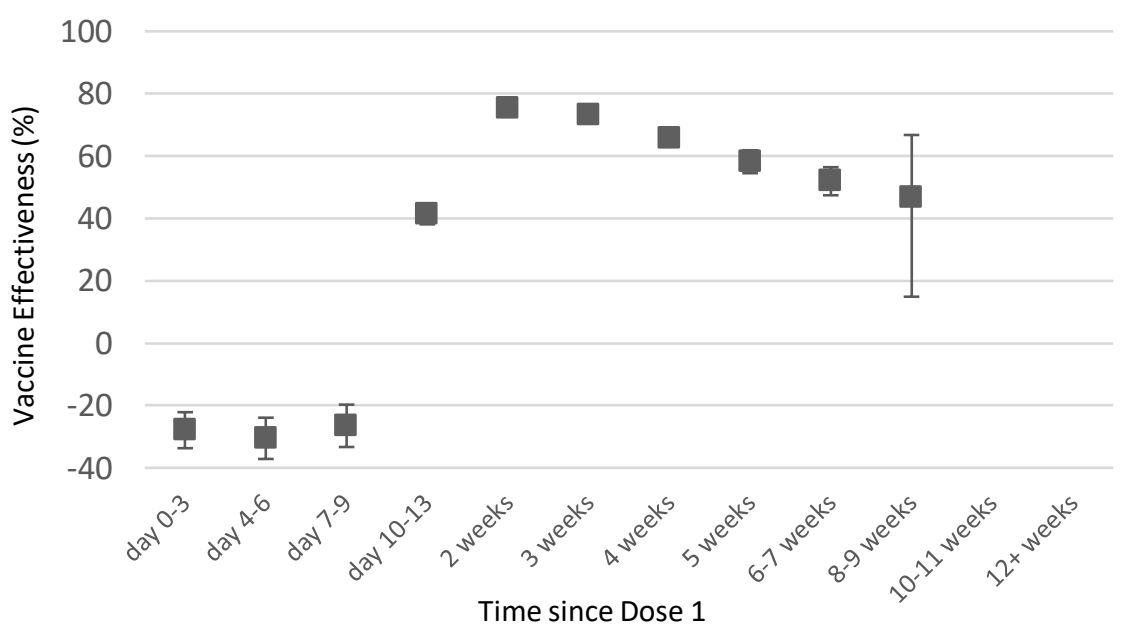

c) 18-39-year-olds

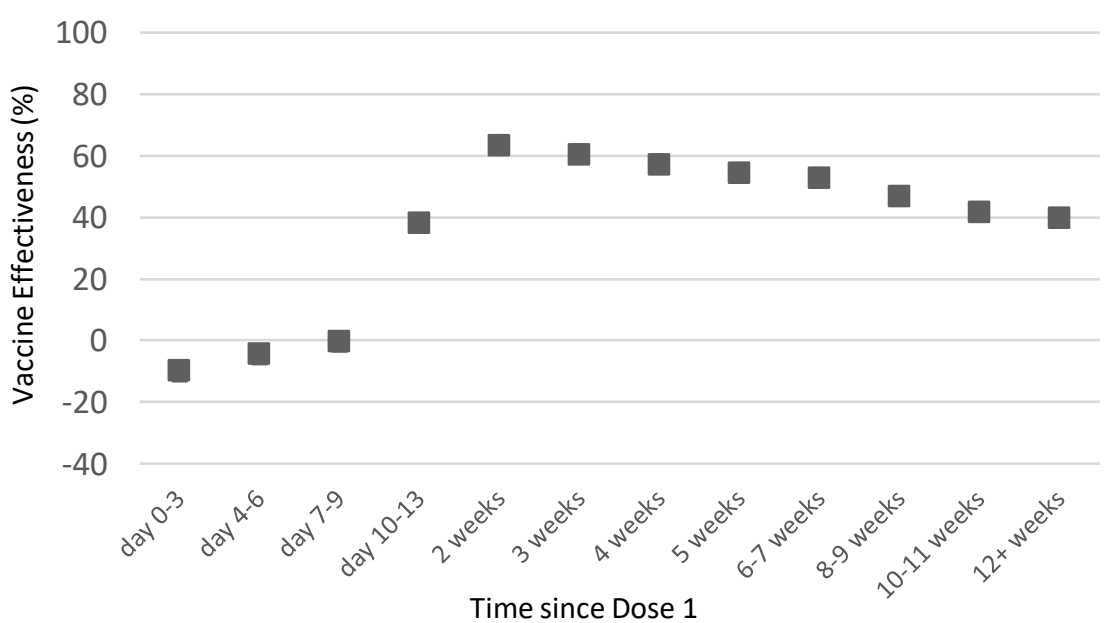

b) 16-17-year-olds

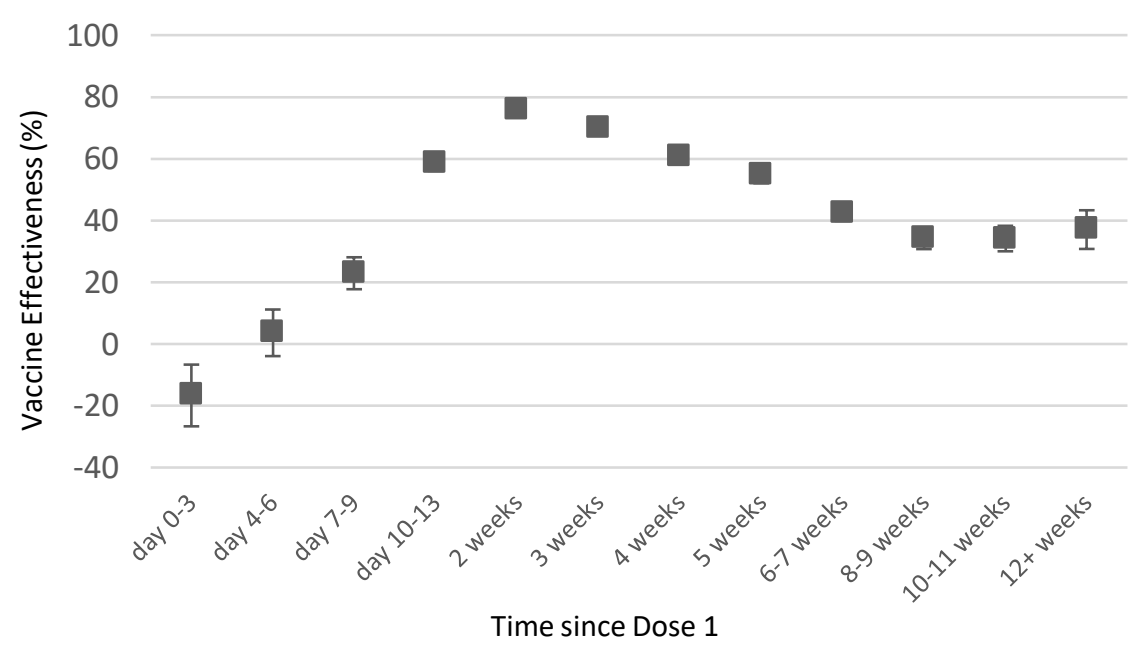

d) 40-64-year-olds

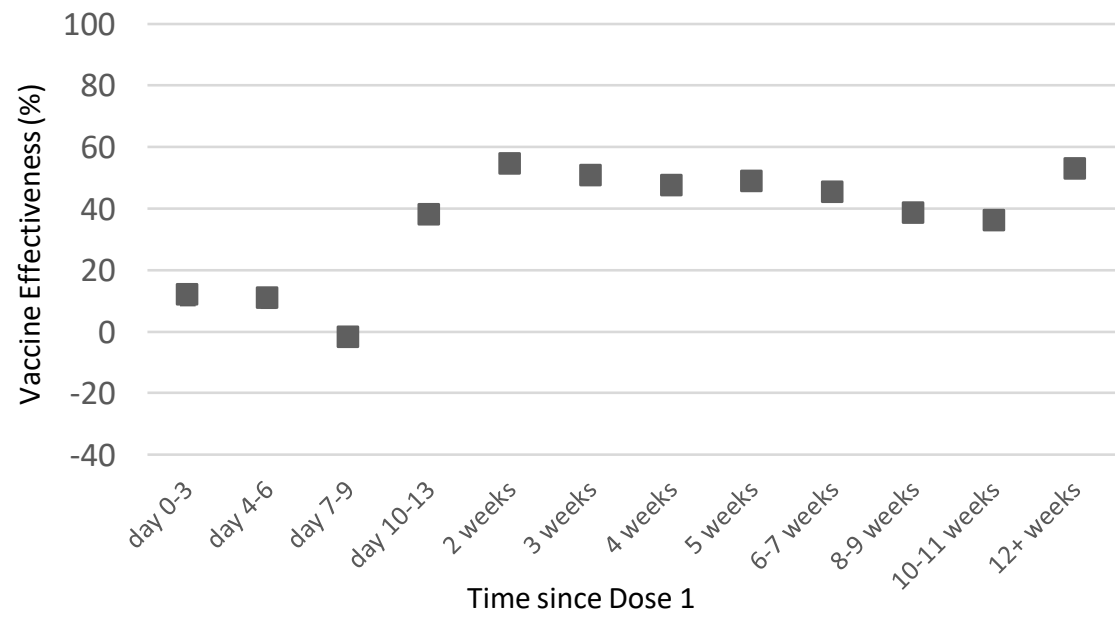


VACCINE EFFECTIVENESS AFTER DOSE 2:

a) 16-17-year-olds

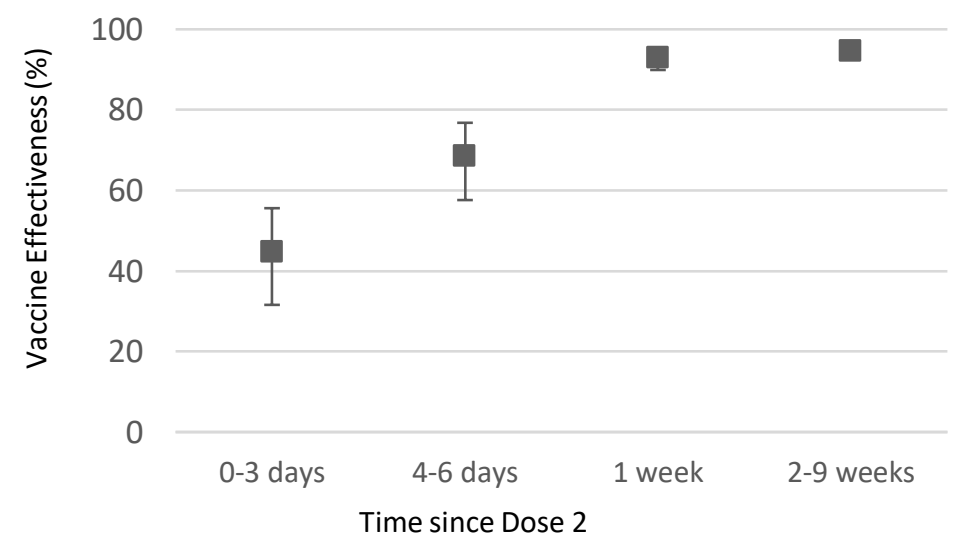

c) 40-64-year-olds

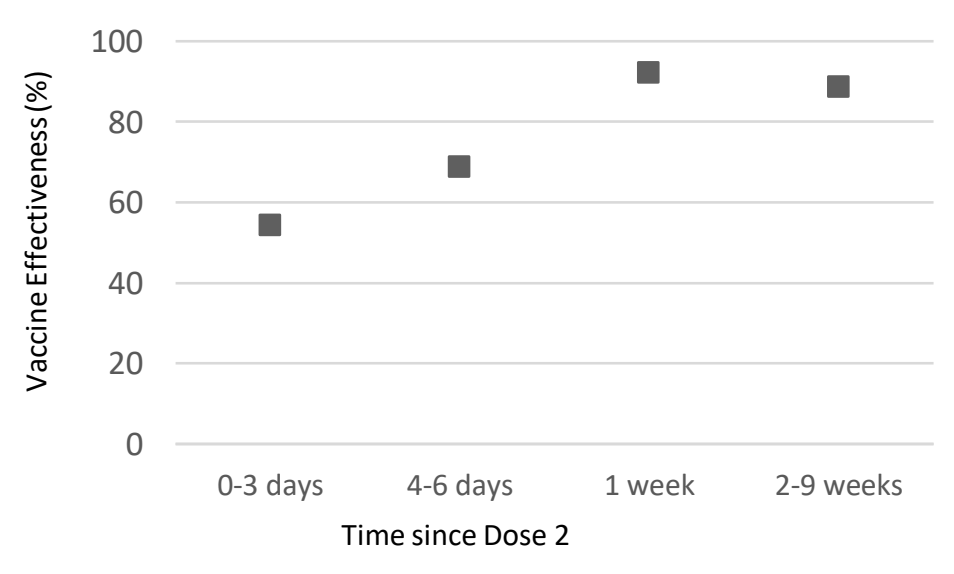

b) 18-39-year-olds

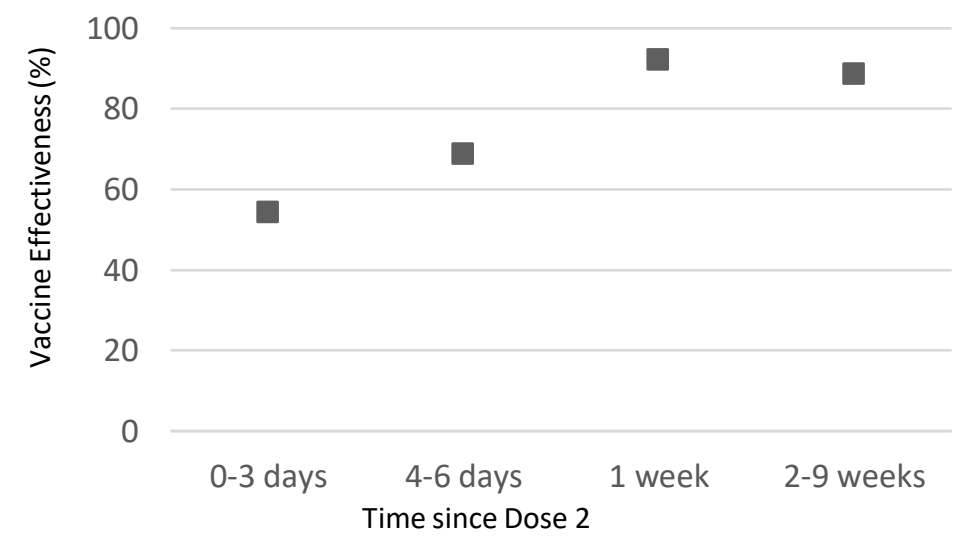

